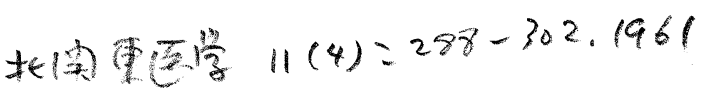

\section{血栓症の成立に関する研究—特に副腎皮質機能と 血液凝固因子の変動に就て}

\author{
塙 移 \\ 群馬大学医学部第 2 内科教室 (主任 中尾喜久 教授 村上元孝 元教授)
}

\section{緒言}

副謷皮質 機能状態が種々の疾病の発現ある いは進展と密接な関係を有することは，近年 Selye $\mathrm{e}^{1 \sim 3)}$ 一泒の研究に端を発し, 次第に明ら かにされてきた。一方心筋梗塞症あるいは脳軟 化症等の動脉血栓症に際し, 発作後血浆中17一 OHCSの上昇が報告されており, ${ }^{4,5)}$ てれらの疾 患の進展にも副腎皮質機能の関与が示唆されて いる.

動脉血栓症の成立機転はなお不明であるが， 血管壁及び血流の変化の他に, 近年に至り, と れら患者において prothrombin，第 7 因子ある いは fibrinogen 増量のあるてとが知られ, ${ }^{6 \sim 99}$ 動物実験における成績と相俟つて, 血液凝固性 の克進が血栓症成立の重要な因子と見做される に至つている. 我々も多数の報告と一致して, てれら疾患において血液凝固性の克進のあるて とを認めたのみでなく, 凝固性六進が心筋梗塞 発作に先行して出現する場合のあるととを臨床 例において確認している，ての血液凝固性の亢 進が如何なる機転によつて招来されるかを明ら かにするととは，本疾患の病態生理の究明に資 するのみでなく，臨床的意義も極めて大きいと 考えられる。

副腎皮質製剂は近年広く臨床的に使用されて おり，副作用として血栓症の発現が認められて いる.さらに ACTH, cortisone 等の投与時, 凝固因子が変化するという報告 ${ }^{11,12)}$ も散見さ れ，副腎皮質機能と血液凝固性の間に何らかの 関連があることが明らかなようである。著者は
これらの事実に着目し，副腎皮質ホルモン投与 時の血液凝固因子の変動を明らかにすると共 に, 心筋梗塞症, 脳軟化症による片麻瘏, 狭心 症，高血圧症患者の副腎皮質機能を測定し，同 時に測定した血液凝固因子活性と対比して興味 ある成績を得たのでこてに報告する.

\section{方法及び材料}

1 血嶈 17-OHCS 測定は Nelson \& Samuels の方 法により, 試薬は下記の如きものを使用した。

a) クロロホルム 使用直前 $\mathrm{K}_{2} \mathrm{CO}_{3}$ から再蒸溜

b ）エーテル 再蒸溜し, 使用直前に硫酸鉄で洗滌

c) フロリシル (60/100mesh Floridin company) エタ,ールにて洗滌後, 電気炉にて $600^{\circ} \mathrm{C}, 4$ 時間加 熱

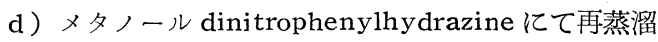

e) 稀硫酸 $310 \mathrm{ml}$ のConc $\mathrm{H}_{2} \mathrm{SO}_{4}$ t $190 \mathrm{ml}$ の $\mathrm{H}_{2} \mathrm{O}$ 亿加光て調製

f) phenylhydrazine $\mathrm{Hcl}$ エタノールより4回再結晶

g) phenylhydrazine硫酸液 使用直前に16mg

phenyl hydrazine Hcl 飞 $10 \mathrm{ml}$ の稀硫酸を加光 て作製

測定方法

早朝空腹時 $M / 10$ 蓚酸ソーダ $2 \mathrm{cc}$ を使用して $20 \mathrm{cc}$ 採 血, 直ちに遠沈により分離した plasma $10 \mathrm{ml}$ に 1.5 倍のクロロホルムを加光て3回抽出, 乙れを減圧乾燥 後, $5 \mathrm{ml}$ のロロホルムに溶解したものを測定に供し た. 直径 $11 \mathrm{~mm}$, 高さ70 $\mathrm{mm} の$ frorisil column にク ロロホルムを流下させ, 乙れに $5 \mathrm{ml}$ の試料を溶解し たクロロホルムを注加し，さらにクロロホルム，2\% メタノ一ル含有クロロホルム夫反 $25 \mathrm{ml}$ で展開し, 次い で $45 \mathrm{ml}$ の $25 \%$ メタノール含有クロロホルムで溶出す 
る。17-OHCS はこの溶出液中に含まれる，てれ势 $50^{\circ}$ Cの water-bath にて減圧乾燥する. 次いでてれを

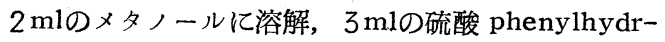
azine を加光， $60^{\circ} \mathrm{C}$ で 1 時間 incubate し, 冷却後 cuvette 入れ, Beckman の spectrophotometer $に$ て定量測定した. 標準曲線は図 1 亿示した如く, hydrocortisonc の 5, 10,15, 20rを夫々メタノール $2 \mathrm{mll}$ 溶解し, 呈色, 測定は上述の如く行つて描いた。

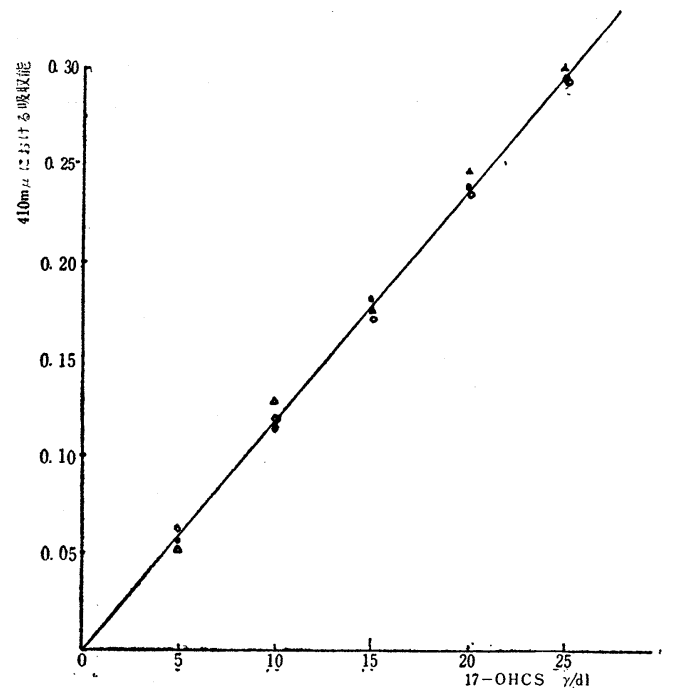

図 1

血漿 17-OHCS 標準曲線

\section{2 血液凝固因子}

次の 4 因子を測定した.

prothrombin時間

prothrombin濃度

第 5 因子

Quickの1段法 ${ }^{14}$

ware \& Seegersの 2 段法

第 7 因子

Lewisの方法 ${ }^{16)}$

Kollerの方法 ${ }^{17}$

採血は各測定法の指示につた。

$$
\text { 対象 }
$$

対象は91例で何れも群馬大学医学部附属病院の外来 及び入院患者である.

高血圧症群は，収縮期血圧 $150 \mathrm{mmHg}$, 拡張期血圧 $90 \mathrm{mmHg}$ 以上, 血栓栓塞症又は 狭心症の 併発を認め ず，臨床諸検查により本態性高血圧症と診断された男 14例，女 4 例で，年令分布は25才より72才まで，平均 年令58.6才であつた.

脳軟化症患者は卒中発作後片麻痻を残し，䠦床的に
診断された男 8 例, 女 2 例, 計10例で, その年令分布 は55才より76才まで，平均64.5才であつた。

狭心症患者13例は何れも狭心症発作を有し，心電図 上 ST，T の変化を証明し得た男10例，女 3 例で，年 令分布は48才より73才まで，平均58.5才であつた。

心筋梗塞患者 13 例は, 何れも入院例で. 定型的心筋 梗塞発作を有し，心電図において明らか梗塞曲線を 認めた男11例，女 2 例で，年令分布は46才より 73才 で，平均年令57才であつた。

prednisolone投与例は何れも入院患者で, 男 5 例, 女12例の計17例であり，ネフローゼ症候群 3 例，心藏 疾患 5 例, 高血症 2 例, 神経系疾患 1 例, ザルコイド -ジス 3 例, 紫斑病, 糖尿病, 結節性動脉各々 1 例で あつた。これらに対し常用量を 1 回又は長期投与して 凝固因子に及ぼす影響を検討した．対象例，投与法の 詳細は表1, 2 亿示した。

別に対象群として12例を本学職員及び健康診断に来 院した外来患者から，8例を前橋養老院老年者より選 んだ. 何れも諸検査成績に著変を認めなかつた者であ る. 男15例，女 5 例，計 20 例で，年令分布は他の疾患 群対象と等しくする為に40才以上の者の中より選出 し，40才より68才に及び平均年令は54.7才であつた。

\section{結果}

1） prednisolone 1 回投与時の血液凝固因子の 変動

測定は，最初の 4 例は投与前及び投与後 3 , $6 ， 9 ， 12$ 時間に行つた。結果は表 1 亿示した 如く, 投与後の変動は何れの例においても 6 9 時間後に最も著名であつた，故に以下 6 例は その時間における測定值を示したものである.

prothrombin 時間の短縮は 10 例中 4 例（case $1 ， 2 ， 3 ， 4$ ), 延長 3 例 (case $5,8,9$ ), 不変 3 例 (case 6, 7, 10) であつた. prothpombin 濃度は, 増加したものは 6 例中 3 例 (case 6, 8,10 ), 不変 2 例 (case 5, 7), 減少 1 例 (case 9), であり，第 5 因子活性は殆んぞ不変，第 7 因子活性は，上昇 5 例 (case 1，2，3，4，6), 不変 4 例 (case 7, 8, 9, 10), 減少 1 例 (case 5), であつた。すなおち約半数の病例において 
(290)

表1

Prednisolone 25mg 1 回投与後の血液凝固因子の変動

\begin{tabular}{|c|c|c|c|c|c|c|c|c|c|c|c|c|c|}
\hline \multirow{2}{*}{$\begin{array}{l}\text { 症例 } \\
\text { 番号 }\end{array}$} & \multirow{2}{*}{ 氏 名 } & \multirow[t]{2}{*}{ 性 } & \multirow[t]{2}{*}{ 年令 } & \multirow[t]{2}{*}{ 疾 患 名 } & \multicolumn{3}{|c|}{$\begin{array}{c}\text { prothrombin時間 } \\
\text { (秒) }\end{array}$} & \multicolumn{2}{|c|}{\begin{tabular}{|l|}
2 段法による \\
prothrombin \\
濃度 $(\mathrm{u} / \mathrm{cc})$ \\
\end{tabular}} & \multicolumn{2}{|c|}{$\frac{\text { 第 } 5 \text { 因子活性 }_{(\%)}}{2}$} & \multicolumn{2}{|c|}{$\underset{(\%)}{\text { 第因子 } 7 \text { 活性 }}$} \\
\hline & & & & & 前 & & 後 & 前 & 後 & 前 & 後 & 前 & 後 \\
\hline \multirow{4}{*}{1} & \multirow{4}{*}{ S.G. } & \multirow{4}{*}{ 우 } & \multirow{4}{*}{20} & \multirow{4}{*}{ 慢 性 腎 炎 } & \multirow{4}{*}{14.2} & \multicolumn{2}{|c|}{3 時間後11.4 } & & & & & \multirow{4}{*}{100} & 140 \\
\hline & & & & & & 61 & " 12.3 & & & & & & 170 \\
\hline & & & & & & 9 & " 13.1 & & & & & & 150 \\
\hline & & & & & & 12 & " 14.0 & & & & & & 140 \\
\hline \multirow{4}{*}{2} & \multirow{4}{*}{ O. K. } & \multirow{4}{*}{$\hat{o}$} & \multirow{4}{*}{47} & \multirow{4}{*}{ 心 筋 梗 塞 } & \multirow{4}{*}{15.0} & \multicolumn{2}{|c|}{ 3時間後14.2 } & & & & & \multirow{4}{*}{100} & 115 \\
\hline & & & & & & 6 & " 14.2 & & & & & & 175 \\
\hline & & & & & & 9 & " 12.8 & & & & & & 150 \\
\hline & & & & & & 12 & " 13.2 & & & & & & 125 \\
\hline \multirow{4}{*}{3} & \multirow{4}{*}{ Y.M. } & \multirow{4}{*}{ ㅇ } & \multirow{4}{*}{56} & \multirow{4}{*}{ 高 血 圧 症 } & & 3 時夙 & 間後15.2 & & & & & & 160 \\
\hline & & & & & 15.5 & 61 & " 14.5 & & & & & 100 & 175 \\
\hline & & & & & & 9 & " 14.3 & & & & & & 150 \\
\hline & & & & & & 12 & $" 14.3$ & & & & & & 115 \\
\hline & & & & & & 3時閏 & 間後14.0 & & & & & & 105 \\
\hline 4 & I. T. & $\hat{o}$ & 61 & 心 筋 梗 塞 & 14.6 & 6 & " 12.0 & & & & & 100 & 115 \\
\hline & & & & & & 91 & " 13.0 & & & & & & 120 \\
\hline & & & & & & 12 & 12.6 & & & & & & 115 \\
\hline 5 & T. N. & 우 & 63 & 高 血 圧 症 & 15.2 & 6時成 & 間後16.3 & 318 & 318 & 100 & 96 & 98 & 78 \\
\hline 6 & T. M. & 우 & 36 & 心 筋 梗 塞 & 15.8 & 9 & " 16.3 & 270 & 283 & 100 & 100 & 100 & 130 \\
\hline 7 & T. C. & 우 & 38 & 側索硬化症 & 16.5 & 6 & " 17.0 & 310 & 310 & 100 & 100 & 97 & 105 \\
\hline 8 & I. H. & 우 & 16 & 紫 斑 病 & 16.2 & 6 & 17.1 & 231 & 249 & 100 & 100 & 98 & 100 \\
\hline 9 & T. S. & 우 & 28 & 僧帽分閉鎖不全 & 16.0 & 6 & 18.4 & 231 & 219 & 100 & 98 & 100 & 100 \\
\hline 10 & T. S. & 우 & 62 & 糖＼cjkstart尿 & 16.8 & 9 & " 16.9 & 276 & 285 & 100 & 100 & 97 & 100 \\
\hline
\end{tabular}

prothrombin 時間の短縮と第 7 因子の増加が認 められた. prednisolone 連用時の成績は表 2 , 図 2 に示した. 投与法及び投与量は表示した如 く, 必ずしも一定でない上, 基礎疾患が異るの
で，てれらの成績を比較検討するのは容易では ないが，検索した 7 例において，1 段法prothrombin時間は1例（case 16）を除いて何れも短 縮するのがみとめられた．２段法によるproth- 
rombin濃度の増加 (case 11, 12, 13, 15), 第 小

括

5 因子活性上昇（case 11，12，13，14，15，

17), 第7因子活性増加 (case 11，12，15，17),

$\mathrm{ACTH}$ 又は副腎皮質ホルモン投与時の副作 等を認めた例も多かつた。乙れら凝固因子の変 用の一つとして血栓症があげられており，また 動が，基礎疾患の別，又は同一疾患において， 臨床像と関連性は認められなかつた。 以上の成 績より，prednisolone 投与例では血液凝固性の 亢進がみられる場合が多いと考光られる。 これらの薬剤は種々の原因による出血傾向の治 療にも用いられ，血液凝固機転との関連が深い と考えられている。 cosgriff ${ }^{18)}$ 等は ACTH， cortisone の連続投与によつて prothrombin時間

表 2

Prednisolone 連続投与時の血液凝固因子の変化

\begin{tabular}{|c|c|c|c|c|c|c|c|c|c|c|c|}
\hline $\begin{array}{l}\text { 症例 } \\
\text { 番号 }\end{array}$ & 氏 名 & 性 & 年令 & 疾 患 名 & $\begin{array}{l}\frac{\text { 投 }}{1 \text { 日量 }} \\
(\mathrm{mg})\end{array}$ & $\begin{array}{c}\text { 与 } \\
\text { 投与 } \\
\text { 昌数 }\end{array}$ & $\begin{array}{c}\text { 法 } \\
\left.\mid \begin{array}{l}\text { 総投与 } \\
\text { 量 }(\mathrm{mg})\end{array}\right]\end{array}$ & $\begin{array}{l}\text { prothro- } \\
\text { mbin } \\
\text { 時間(秒) }\end{array}$ & 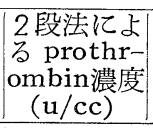 & $\begin{array}{c}\text { 第 } 5 \text { 因子 } \\
\text { 活 } \\
(\%)\end{array}$ & $\begin{array}{l}\text { 第 } 7 \text { 因子 } \\
\text { 活 } \\
(\%)\end{array}$ \\
\hline \multirow{3}{*}{11} & \multirow{3}{*}{ T. S. } & \multirow{3}{*}{$\hat{o}$} & \multirow{3}{*}{73} & \multirow{3}{*}{$\begin{array}{l}\text { 心筋 梗 塞 } \\
\text { 紅 皮 症 }\end{array}$} & 投 & 与 & 前 & 18.0 & 250 & 90 & 65 \\
\hline & & & & & 5 & 50 & 340 & 14.0 & 280 & 100 & 95 \\
\hline & & & & & 20 & 60 & 540 & 14.5 & 300 & 100 & 100 \\
\hline \multirow{3}{*}{12} & \multirow{3}{*}{ T.M. } & \multirow{3}{*}{ 우 } & \multirow{3}{*}{21} & \multirow{3}{*}{ 慢 性 腎 炎 } & 投 & 与 & 前 & 13.5 & 300 & 100 & 100 \\
\hline & & & & & \multirow{2}{*}{25} & 5 & 125 & 10.5 & 330 & 105 & 165 \\
\hline & & & & & & 10 & 250 & 10.5 & 330 & 110 & 130 \\
\hline \multirow{5}{*}{13} & \multirow{5}{*}{ Y. T. } & \multirow{5}{*}{ ㅇ } & \multirow{5}{*}{30} & \multirow{5}{*}{ 結節性動脉炎 } & 投 & 与 & 前 & 14.5 & 280 & 100 & 105 \\
\hline & & & & & \multicolumn{3}{|c|}{ " } & 15.5 & 290 & 100 & 105 \\
\hline & & & & & קח & 6 & 180 & 13.0 & 300 & 100 & 105 \\
\hline & & & & & 1 & 14 & 385 & 13.0 & 300 & 100 & 105 \\
\hline & & & & & 30 & 24 & 585 & 12.5 & 310 & 105 & 105 \\
\hline \multirow{4}{*}{14} & \multirow{4}{*}{ N.M. } & \multirow{4}{*}{ 우 } & \multirow{4}{*}{18} & \multirow{4}{*}{$\begin{array}{l}\text { ザルコイドー } \\
\text { ジス }\end{array}$} & 投 & 与 & 前 & 14.0 & 300 & 100 & 100 \\
\hline & & & & & \multirow{3}{*}{$\begin{array}{c}15 \\
1 \\
25\end{array}$} & 6 & 145 & 13.5 & 300 & 100 & 100 \\
\hline & & & & & & 16 & 320 & 13.5 & 300 & 105 & 100 \\
\hline & & & & & & 27 & 485 & 13.0 & 300 & 105 & 100 \\
\hline \multirow{3}{*}{15} & \multirow{3}{*}{ K. M. } & \multirow{3}{*}{$\hat{o}$} & \multirow{3}{*}{19} & \multirow{3}{*}{ 慢性 腎 炎 } & 投 & 与 & 前 & 15.0 & 250 & 98 & 94 \\
\hline & & & & & 10 & 2 & 50 & 13.2 & 270 & 105 & 130 \\
\hline & & & & & 25 & 27 & 550 & 14.2 & 270 & 100 & 100 \\
\hline \multirow{2}{*}{16} & \multirow{2}{*}{ K. H. } & \multirow{2}{*}{$\hat{0}$} & \multirow{2}{*}{20} & ザルコイドー & 10 & 20 & 490 & 12.0 & 260 & 115 & 120 \\
\hline & & & & & 25 & 47 & 945 & 14.0 & 250 & 100 & 105 \\
\hline 17 & $T$ & 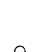 & 17 & 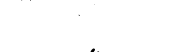 & 投 & 与 & 前 & 14.0 & & 100 & 100 \\
\hline & & & & & 25 & 6 & 150 & 12.5 & & 110 & 110 \\
\hline
\end{tabular}




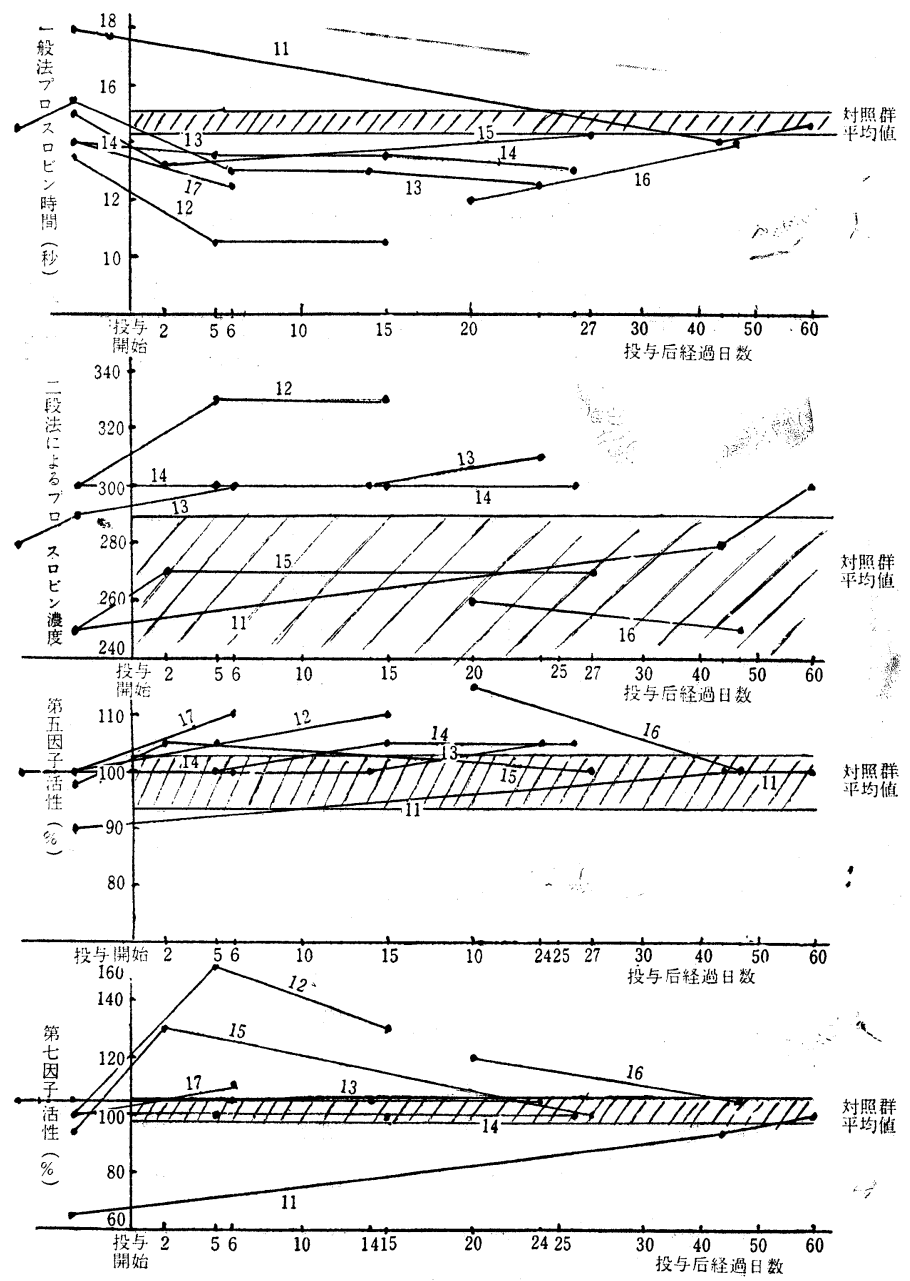

図 2

Prednjsolone 連用時の血液凝固因子の変化

に一定の変動を認めなかつたと報告しているが Forattini ${ }^{19}$ 等は ACTHの大量長期投与で prothrombin 能の上昇, 第5因子活性の軽微な増加 を報告しており，Günther u Kiefer 等はcortison, prednisolone の 1 週間連用により第 5 及 び第 7 因子活性と共に prothrombin能が明らか に増加するてとを指摘している。 de Nicola ${ }^{21)}$ cortison 及び ACTH 投与による第 7 因子活性 の増加を認めている，著者の成績では上述の如 $く$, prednisolone 1 回投与後に既に各種凝固因 子に有意の変動を認めた例が多く, 長期連用に
より, 多くの例において prothrombin 時間の短 縮, prothrombin 濃度の増加, 第 5 , 第 7 因子 活性の上昇等を認めた。

2）各疾患群における血浆 17-OHCS level に 就いて

成績は表 $3 \sim 7$ 亿示した如く，健康成人 20 例 では $7.0 r / \mathrm{dl} よ り 13.2 \gamma / \mathrm{dl}$ 亿分布し, 算術平均 值は $10.6 \mathrm{r} / \mathrm{dl}, 5 \%$ 危険率における母平均の 信頼限界は10.6-0.8r/dl〜10 6+0.8r/dlであ

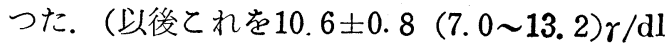
の如く記載す） 
(293)

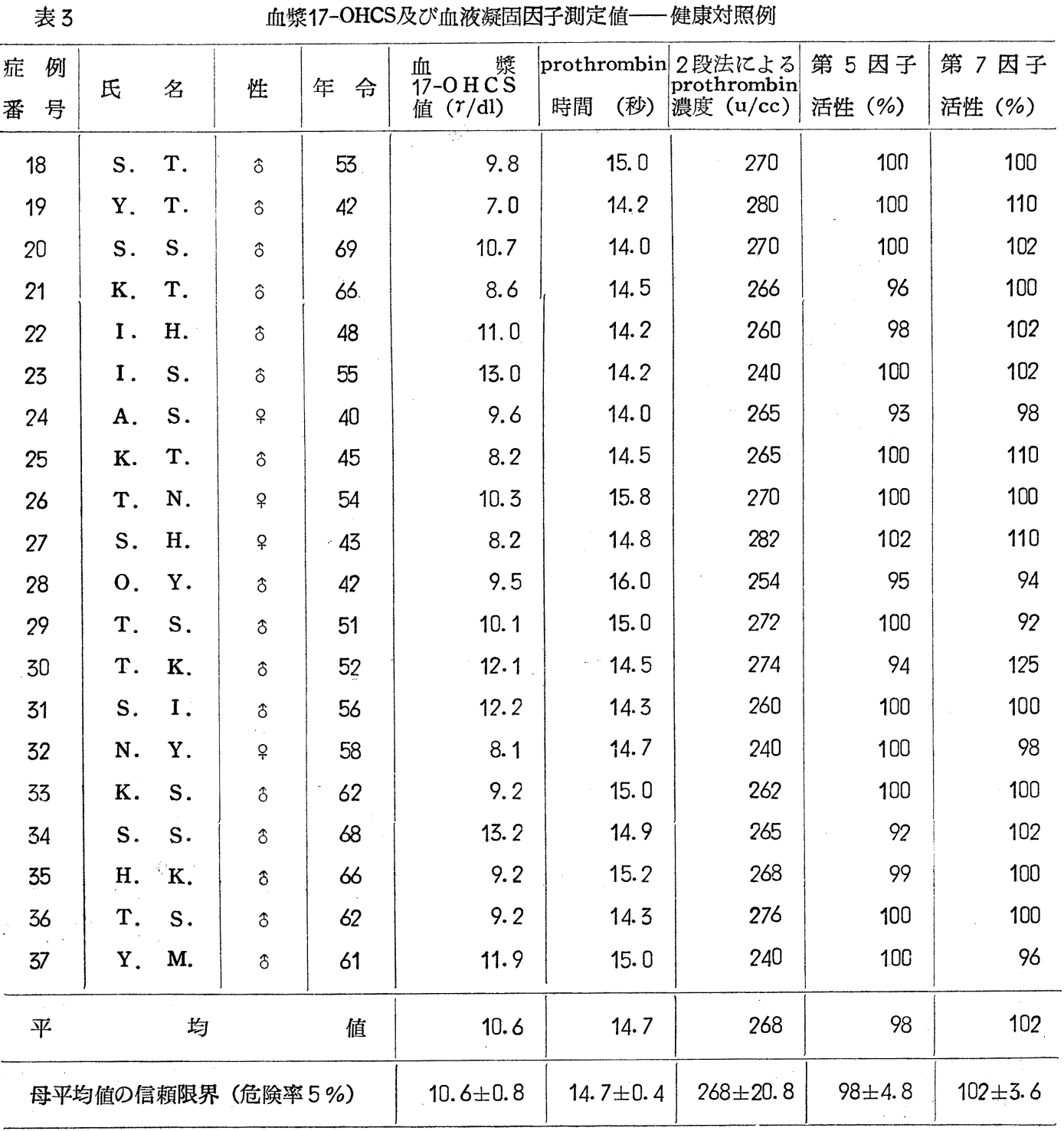


高血圧患者血漿17-OHC值及び血液凝固因子測定值

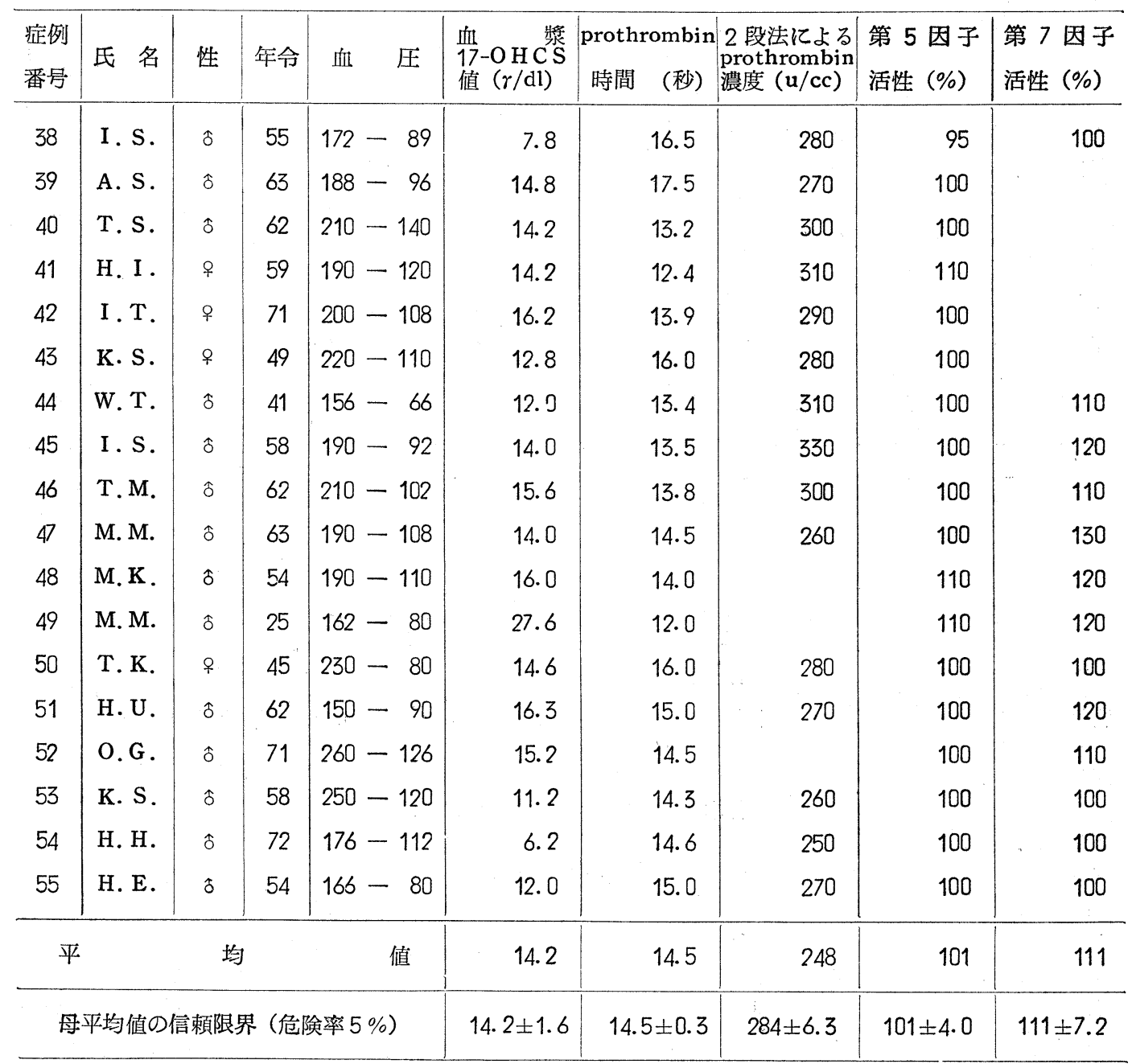


(295)

\begin{tabular}{|c|c|c|c|c|c|c|c|c|c|c|c|}
\hline \multicolumn{4}{|c|}{ 表 5} & \multicolumn{6}{|c|}{ 脳軟化昰患者血漿17-OHCS值及び血液凝固因子測定値 } & \\
\hline $\begin{array}{l}\text { 症例 } \\
\text { 番号 }\end{array}$ & 氏 & 名 & 性 & 年 令 & $\begin{array}{l}\text { 発作後 } \\
\text { 日 数 }\end{array}$ & $\begin{array}{l}\text { 血 } 17-\mathrm{OHC} S \\
\text { 值 }(r / \mathrm{dl})\end{array}$ & $\begin{array}{l}\text { prothr } \\
\text { 時間 }\end{array}$ & $\begin{array}{l}\text { omibn } \\
\text { (秒) }\end{array}$ & $\begin{array}{l}2 \text { 段法による } \\
\text { prothromibn } \\
\text { 濃度 }(u / c c)\end{array}$ & $\begin{array}{l}\text { 第 } 5 \text { 因子 } \\
\text { 活性 (\%) }\end{array}$ & $\begin{array}{l}\text { 第 } 7 \text { 因子 } \\
\text { 活性 (\%) }\end{array}$ \\
\hline 56 & & S. & ㅇ & 69 & 30 & 17.7 & & 14.1 & 310 & 100 & 120 \\
\hline 57 & & I. & $\hat{o}$ & 63 & 50 & 12.0 & & 12.8 & 300 & 105 & 115 \\
\hline 58 & & $\mathrm{Y}$. & $\hat{s}$ & 56 & 60 & 12.0 & & 14.0 & 260 & 105 & 115 \\
\hline 59 & & $\mathrm{H}$. & ồ & 63 & 25 & 14.0 & & 14.5 & 260 & 100 & 130 \\
\hline 60 & & M. & o & 76 & 60 & 13.6 & & 14.2 & 240 & 100 & 110 \\
\hline 61 & & $\mathrm{H}$. & 우 & 56 & 42 & 18.2 & & 13.0 & 291 & 104 & 125 \\
\hline 62 & & $\mathrm{~N}$. & $\hat{o}$ & 71 & 31 & 18.9 & & 12.6 & 270 & 108 & 115 \\
\hline 63 & & R. & $\hat{o}$ & 73 & 362 & 12.0 & & 14.0 & & 105 & 110 \\
\hline 64 & & I. & $\hat{o}$ & 55 & 780 & 12.6 & & 14.0 & & 98 & 100 \\
\hline 65 & & M. & $\hat{o}$ & 63 & 54 & 21.0 & & 10.5 & 250 & 105 & 130 \\
\hline 平 & & & 均 & & 値 & 15.2 & & 13.3 & 273 & 103 & 117 \\
\hline & 平均 & の信 & 限界 & 危険率 & & $15.2 \pm 3.6$ & 13.3 & \pm 1.3 & $273 \pm 14.5$ & $103 \pm 2.3$ & $117 \pm 6.9$ \\
\hline
\end{tabular}

表6

狭心症患者血嶈17-OHCS值及び血液凝固因子測定值

\begin{tabular}{|c|c|c|c|c|c|c|c|c|c|c|c|}
\hline $\begin{array}{l}\text { 症例 } \\
\text { 番号 }\end{array}$ & 氏 & 名 & 性 & 年 令 & \begin{tabular}{|l} 
発 作 後 \\
経過(日)
\end{tabular} & $\begin{array}{l}\text { 血 } \mathrm{OHC} \text { 漿 } \\
\text { 值 }(r / \mathrm{dl})\end{array}$ & $\left\{\begin{array}{l}\text { prothr } \\
\text { 時間 }\end{array}\right.$ & $\begin{array}{c}\text { rombir } \\
\text { (秒) }\end{array}$ & $\begin{array}{c}\mathrm{n}^{\prime} 2 \mathbf{E} \text { 法による } \\
\text { prothrombin } \\
\text { 濃度 (u/cc) }\end{array}$ & $\begin{array}{l}\text { 第 } 5 \text { 因子 } \\
\text { 活性（\%） }\end{array}$ & $\begin{array}{l}\text { 第 } 7 \text { 因子 } \\
\text { 活性 (\%) }\end{array}$ \\
\hline 66 & H. & & $\hat{o}$ & 55 & 10 & 14.2 & & 14.8 & 260 & 100 & 100 \\
\hline 67 & & $\mathrm{Y}$. & $\hat{o}$ & 56 & 発作中 & 25.9 & & 12.9 & 268 & 110 & 120 \\
\hline 68 & $\mathrm{~K}$. & s. & $\hat{o}$ & 49 & 20 & 12.8 & & 15.0 & 250 & 100 & 100 \\
\hline 69 & & & ô & 67 & 15 & 15.1 & & 14.0 & 260 & 100 & 110 \\
\hline 70 & & $z$. & $\hat{o}$ & 66 & 頗 発 & 14.6 & & 14.2 & 276 & 110 & 110 \\
\hline 71 & I. & T. & $\hat{o}$ & 59 & 16 & 11.2 & & 15.0 & 260 & 100 & 100 \\
\hline 72 & Y. & $\mathrm{K}$. & 우 & 48 & 頗 発 & 17.0 & & 13.0 & 270 & 98 & 120 \\
\hline 73 & & H. & 우 & 61 & 20 & 14.6 & & 15.1 & 266 & 100 & 110 \\
\hline 74 & & s. & $\hat{o}$ & 67 & 頗 発 & 13.6 & & 13.6 & 275 & 103 & 130 \\
\hline 75 & & $\mathrm{R}$. & 우 & 73 & 30 & 9.0 & & 16.5 & 260 & 100 & 95 \\
\hline 76 & & W. & $\hat{o}$ & 49 & 12 & 12.8 & & 16.0 & 270 & 100 & 100 \\
\hline 77 & & M. & $\hat{o}$ & 55 & 発作中 & 14.2 & & 13.5 & 262 & 120 & 140 \\
\hline 78 & I. & $\mathrm{K}$. & $\hat{\delta}$ & 56 & 20 & 12.2 & & 14.6 & 260 & 95 & 110 \\
\hline \multicolumn{2}{|c|}{ 平 } & \multicolumn{3}{|c|}{ 均 } & 值 & 14.4 & & 14.5 & 264 & 102 & 112 \\
\hline \multicolumn{6}{|c|}{ 母平均值の信頼限界（危険率 5\%) } & $14.4 \pm 1.4$ & 14.5 & $5 \pm 1.6$ & $264 \pm 5.8$ & $102 \pm 5.0$ & $112 \pm 7.3$ \\
\hline
\end{tabular}


(296)

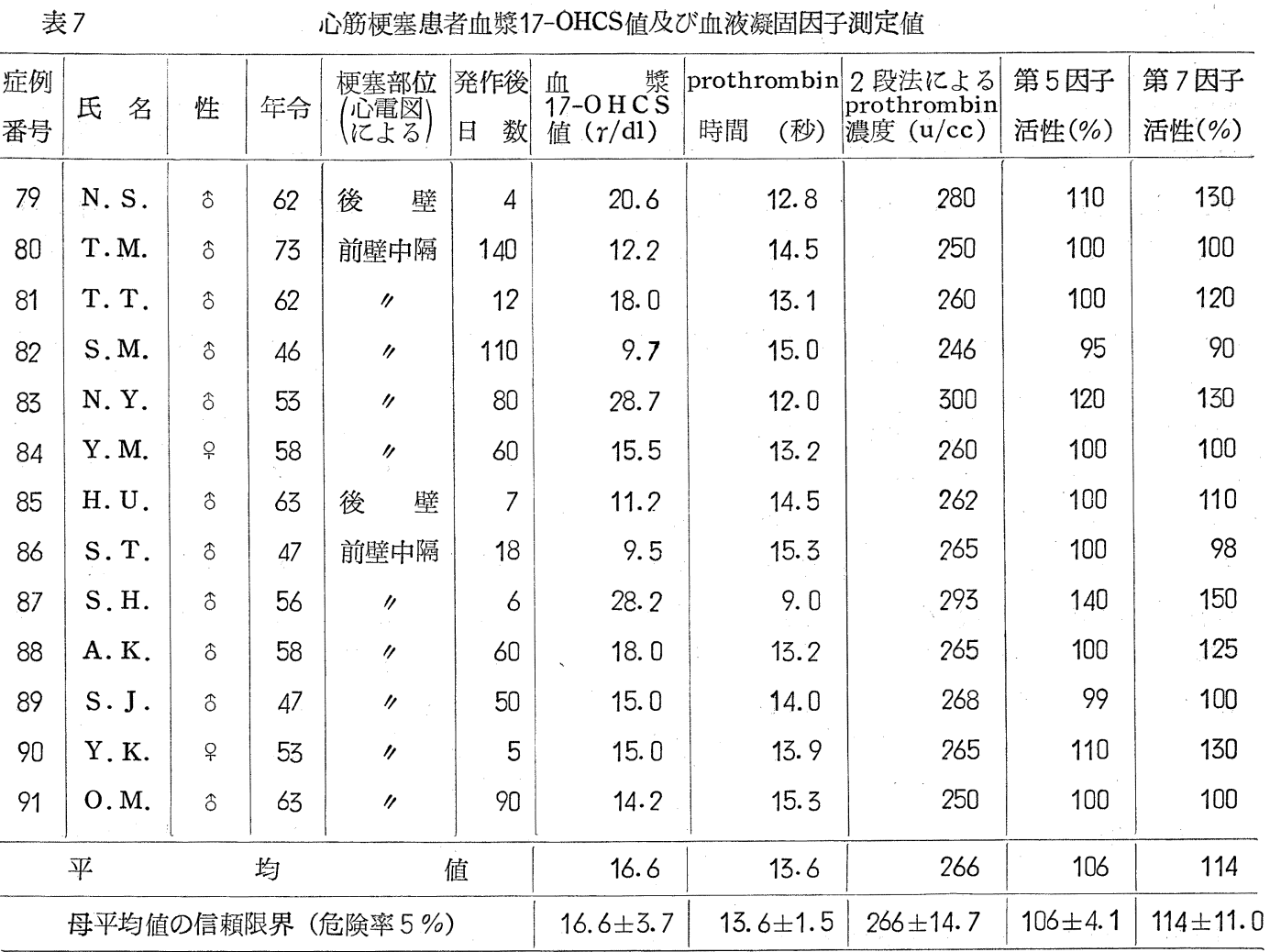

高血圧症患者血漿では14.2 $1.6(6.2 \sim 27.6)$ $\gamma / \mathrm{dl}$, 脳軟化症患者では $15.2 \pm 3.6$ (12.0 $21.0) \gamma / \mathrm{dl}$ ，狭心症群は $14.4 \pm 1.4(9.0 \sim 25.9)$ $\gamma / \mathrm{dl}$ ，心筋梗塞患者では16.6士3.7(9.5〜28.7) r/dlであつた。これらの值を推計学的に検討す ると, 疾患群では何れにおいても健康者対照群 に比し， $5 \%$ の危険率において有意の増加を認 めた。 各疾患群相互の検討では, 有意差を認め たものはなかつたが, 脳軟化群及び心筋梗塞群 では, 高血圧群及び猏心腚群の何れよりも平均 值は高值を示した。乙れら両群において, 発作 後の時間的経過と血漿 17-OHCS level の関係 を検討するには, 症例数が充分であるとは言い 難いが，心筋梗塞発作 1 ケ月以内に測定した 6 例に於ける平均值は $18.2 \gamma / \mathrm{d}$ 亿対し, 以後に測 定した 7 例の平均值は $15.4 \gamma /$ / で, 前者におい 均明らかに高值であり, 発作後経過時間の短か
いものでは 17-OHCS level が高い傾向がうか がわれた。脳軟化群では新鮮例が少いが, 発作 後 2 ケ月以内に測定した 8 例の平均值 $15.9 \mathrm{r} / \mathrm{dl}$ は, 以後の 2 例の平均值 $12.3 \gamma / \mathrm{dl}$ 亿比して明ら かに高值で, こてにおいても新鮮例における高 值の傾向がうかがわれた。

\section{小 括}

Nelson \& Samuels 法で測定した高血圧症, 脳軟化症, 狭心症, 心筋梗塞症の血嶈17-OHCS 值は, 何れも対象群に比し高值を示し, 推計学 的に有意差を認めた. 酸化還元の代謝障害, 腎 障害の関与等も考えねばならないが，てれらの 疾患においては副腎皮質機能がえ進状態にある と考学て良いと思はれる。就中有意差は認めら れなかつたとはいえ, 兴軟化群及び心筋梗塞 群, 特に新鮮例において, 17-OHCS が高值の 
傾向を示したのは興味深い，既に $\mathrm{Okg}^{22}$ は1956 年に脳軟化症でPorter \& Silber変法による血 嶈 17-OHCS 值を報告しており, 発作後 1 週間 は高值を示し，特に予後不良例でい上昇が著明 で, 平均值が $44.3 \pm 4.54$ r/dlであつたと述べて いる. 著者の測定対象には Okaの如き新鮮例は 含まれていなかつたが，なお健康者に比して高 值であり，新鮮例において，より高い傾向を認 めた。筋梗塞では Engel ${ }^{4}$ 等が血中17-OHCS の増量を認めており, Forsmann は発作後 1 〜 4 日にわたつて尿中glucocorticoid, 17-ketosteroid の排泄の増量を認めている. Feldthusen \& Lassen ${ }^{23}$ も心筋梗塞後の血清鉄の低下及び副 腎皮質との関係に論及している。 $\mathrm{OKa}^{4}$ も心筋 梗塞12例, 狭心症8例の血漿 17-OHCS を Silber \& Porter 法のPeterson変法で測定し, 心筋梗 塞, 狭心症の何れにおいても発作直後は極めて 高值となり，心筋梗塞では平均 $26.8 \pm 1.85 \mathrm{r} / \mathrm{dl}$ 狭心症平均 $19.4 \pm 1.9 \mathrm{r} / \mathrm{dl}, 3$ 週前後で大多数 が正常值に復すると言つている，著者の結果も 略々てれらの報告と一致しており，心筋梗塞例 において，上昇が高度である傾向を認めた。乙 れら心臓発作又は脳卒中後の 17-OHCS 増加の 機構は， stress に対する反応として説明されて いる場合が多いようである. 著者の検討では， 新鮮例における増量の一部は stressにより説明 出来るとしても，発作後 1 ケ月前後を経過した 症例においてもなお健康対照群に比して高值で あり，てれら発作を全く認めなかつた高血圧群 においても，健康 対照群に比して高值であつ た. 従つててれら疾患の 17-OHCSの増加を stress によつてのみ説明するのは困難であると の印象を受けている。

3）各疾患群における凝固因子の変動

主として凝固の第 2 段階に関与する因子を各 対象に就き血漿 17-OHCS 測定と同時に測定し た. 結果は表 $3 \sim 7$ 亿示した㞦くである. 1 段 法prothrombin時閒は，健康刘照群の $14.7 \pm 0.4$

（14.0１6.0）秒に刘し, 高血圧群 $14.5 \pm 0.3$
（12.0 17. 5）秒, 脳軟化群 $13.3 \pm 1.3$ (10.5

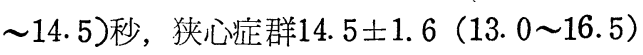
秒, 心筋梗塞群 $13.6 \pm 1.5$ (9.0 15.3) 秒であ り, 高血圧群, 狭心症群を除き, 他の疾患群は 対照群に比し $5 \%$ の危険率において有意の短縮 を認めた．各群における 2 段法による prothrombin 濃度測定值は夫々 $268 \pm 20.8 （ 240 \sim 282 ）$ u/ce, $284 \pm 6.3(250 \sim 330)$ u/ce, $273 \pm 14.5$ $(240 \sim 310) \mathrm{u} / \mathrm{cc}, 264 \pm 5.8(250 \sim 276) \mathrm{u} / \mathrm{cc}$, $266 \pm 14.7(246 \sim 300)$ u/cc であり, 何れの疾 患群においても対照群との間に有意差を認め得 なかつた。

第 5 因子活性の各群における測定值は夫々 98 \pm 4.8 (92 102) \%, 101 $\pm 4.0(95 \sim 110) \%$, $103 \pm 2.3(98 \sim 108) \%, 102 \pm 5.0(95 \sim 120)$ $\%, 106 \pm 4.1$ (95 140)\%であり，心筋梗塞群 においてのみ有意の増加を認めた.

第 7 因子活性の各群における測定值は $102 \pm$ $3.6(92 \sim 125) \%, 111 \pm 7.2(100 \sim 130) \%$, $117 \pm 6.9(100 \sim 130) \%, 112 \pm 7.3(95 \sim 140)$ $\%, 114 \pm 11.0$ (98〜130) \%であつて，5\%の 危険率において有意の高值を示した。各疾患群 間には有意差を認めなかつたが，脳軟化群，心 筋梗塞群ではより高值を示すものが多かつた，

小 括

以上述べた如く, てれら疾患に共通に認めら れたのは第 7 因子活性の上昇であり, 第 5 因子 活性は心筋梗塞群にのみ有意の上昇を認め, prothrombin 濃度には有意差を認めなかつたが 1 段法 prothrombin 時間は高血圧群. 狭心症群 以外の疾患群において短縮し，てれら疾患例特 に脳軟化症, 心筋狭塞症では血液凝固性の元進 があると考光て良いように思はれる。乙れら奖 患における凝固因子の変動は, 教室の長谷川 ${ }^{24}$ 生方, ${ }^{25)}$ 松沢, ${ }^{26)}$ 大塚 ${ }^{27)}$ 等により詳細に検討さ れており，絬果は勿論著者のそれと一致して血 液凝固性の亢進が指摘されている。なお fibri- 
nogen 増加及び第 1 段階に関与する因子の活性 増加も認められている。これらの結果はまた諸 家の報告とも一致しており，心筋梗塞において 発作後 2 週間前後の時期より始まる一過性の血 液性低下相を除き，一般に凝固性の亢進が指摘 されている. 教室の松沢 ${ }^{26)}$ は, 症例数は少いが 心筋梗塞症において, 梗塞発作に先行して血液 凝固性が急激に増加するのを認めており，てれ ら凝固能六進が血栓栓塞症の結果でなく，原因 であると考えられる成績を得ている.

4）血漿 17-OHCS と血液凝固因子との関係

以上の成績より高血圧症, 狭心症, 心筋梗塞 症, 脳軟化定等の疾患例では, 血漿 17-OHCS 值の上の上昇と共に血液凝固性の㐫進が認めら れ，乙れらの変化は後 2 者の疾患すなわち血栓 症において特に著しい事が明らかとなつた。て てでてれら疾患例 及び対照例において，血漿 17-OHCS level c血液凝圆因子測定值の関連 性を検討した，結果は図 3 亿示した如く，pro-

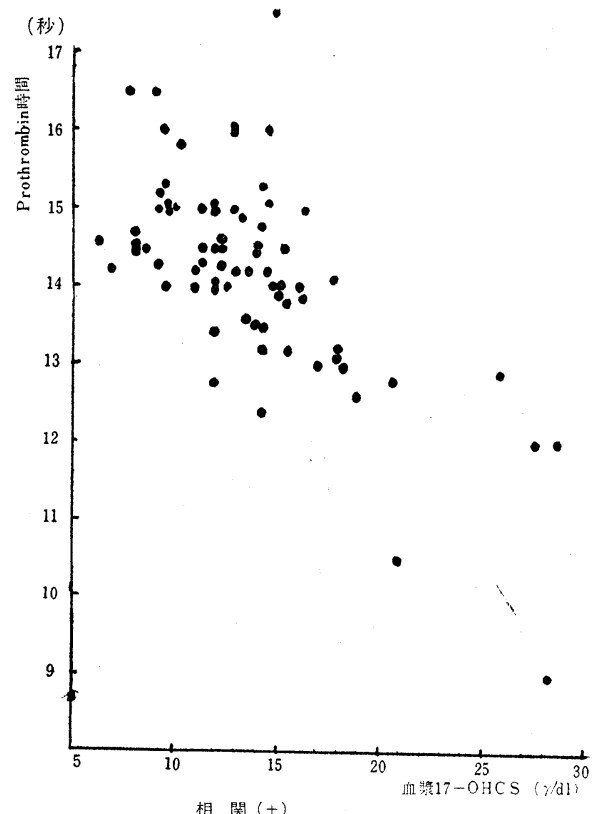

図 3

1段法prothrombin時間と血漿17-OHCS との関係 相関係数 $=0.572$ thrombin 時間は 17-OHCS 值の上昇に従つて 短縮する傾向が認められ，有意の逆相関係を示 した.（相関係数 $\gamma=-0.572 ） 2$ 段法による prothrombin 濃度は図 4 亿示した如く, 測定值 は広く一様に分散し，一定の傾向はみられなか つた. $(r=0.252)$ 図 5 亿は第 5 因子活性之 17-OHCS の相関図を示した。図より明らかな 如く, 第 5 因子活性の増加に従つて 17-OHCS の増加が認められ，有意の相関関係が認められ た。（ $\gamma=0.670 ）$ 第 7 因子活性も図 6 亿示した 如く, 第 5 因子活性之同椂有意の相関関係を認 めた. $(\gamma=0.432)$

\section{総括並に考案}

以上著者は高血圧症, 狭心症, 心筋梗塞症及 び脳軟化症例において，血中 17-OHCS 值を測 定すると同時に，主として凝固の第 2 段階に関 与する凝固因子を測定し, 対照群に比し,てれら

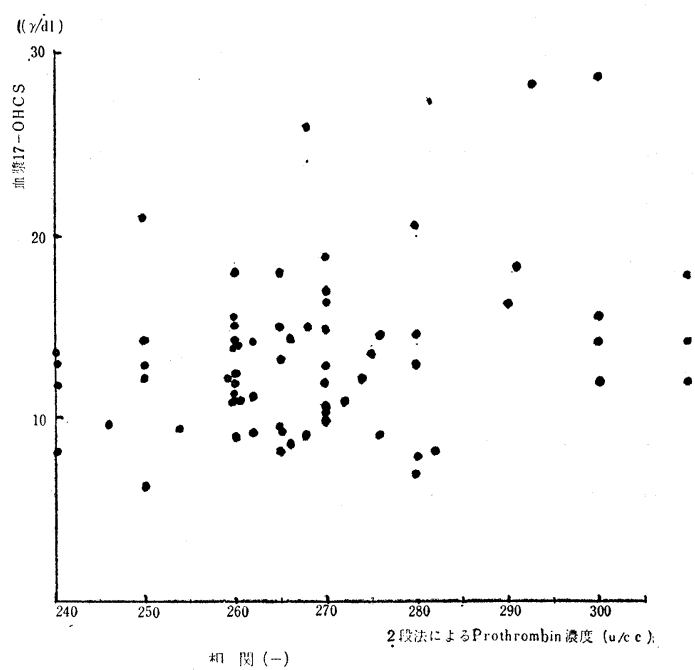

図 4

2段法によるProthrombin濃度と血漿17-OHCS と の関係

相関係数 $=0.252$ 
(299)

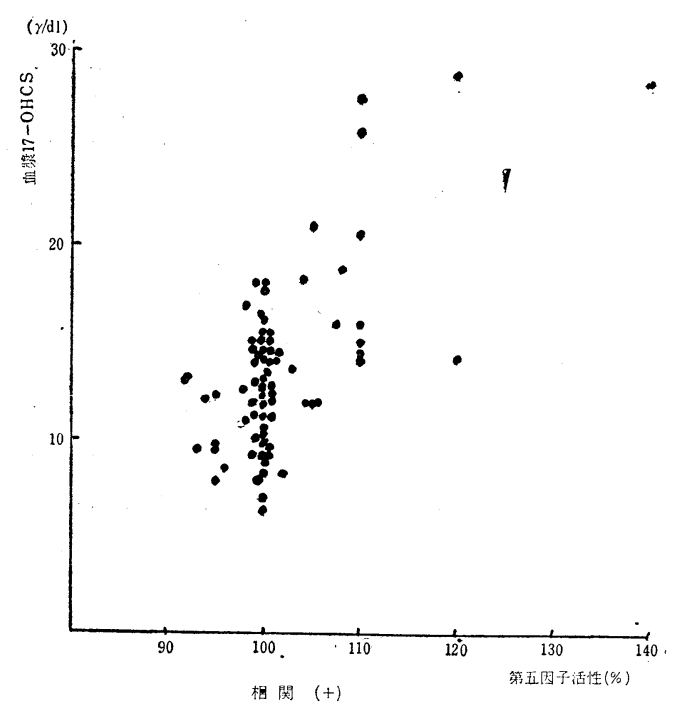

図 5

第 5 因子活性と血嶈17-OHCS との関係

相関係数 $=0.670$

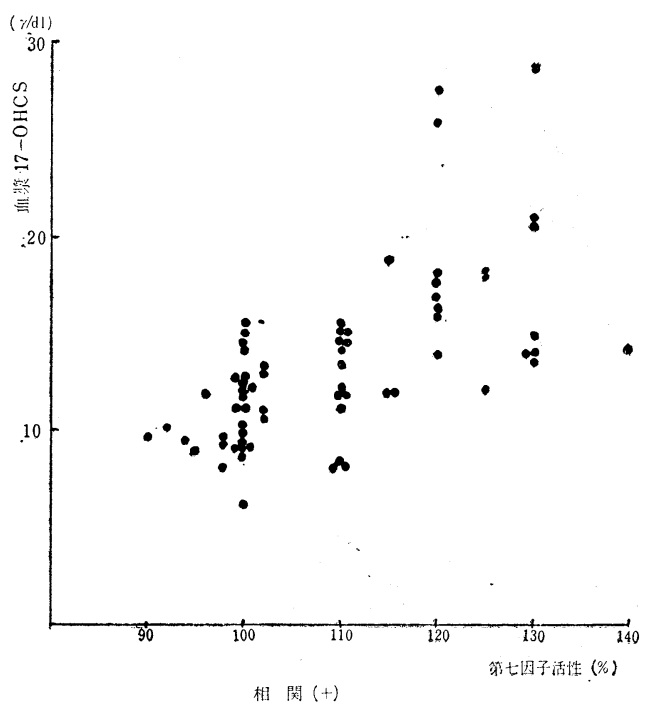

図 6

第 7 因子活性と血嶈17-OHCS との関係

相関係数 $=0.432$

諸家によつても副腎皮質ホルモン投与により， 血液凝固性の六進が招来されることが指摘され ており，かかるが故に ACTH 或は副腎皮質木 ルモンが, 出血傾向の治療に使用され, 又長期 投与例において，血栓症の併発を認めると考え られる. 血液凝固性の著しい方進が既に心筋梗 塞発作直前に認められた事は，乙の変化が梗塞 発作の結果ではなく，むしろ原因の一つをなし ているととを示唆するものであると考えられ る、脳軟化症例では, 発作前に血液凝固性穴進 を示す症例を経験し得なかつたが，心筋梗塞症 の成立機転と関連して考えれば，乙てでも凝固 性六進が結果というよりむしろ原因の一つであ ると考えた方が妥当のようである.しからばて の発作前にみられる急激な血液凝固性の元進が 何に由来するのであろうか. これら血栓症の前 階程とも考党られる高血圧症及び狭心症におい ても，既に 17-OHCS の有意の上昇に伴い，軽 度ではあるが血液凝固性の克進もみられてお り，血栓成立による発作後には著明な17-OHC $\mathrm{S}$ 值の上昇が認められることより，発作前にみ 
られた急激な凝固性㝋進が，何らかの機転で副 腎皮質機能の元進に基いているという可能性を 否定する事は出来ないと思われる．著者は未だ 症例の得られないままに，発作前における 17OHCS level の変動を検討する機会を得ていな いが，著者等の教室に入院した73才の erythrodermiaの 1 症例において, 副腎皮質ホルモン 投与後 4 日目に心筋梗塞発作が招来されたとい う事実は，乙の仮説を裏付ける根拠の一つとな り得ると考えている. 勿論てれらの機構は未だ ほとんぞ不明であり，今後に残された課題の一 つと思われる.

結

語

prednisolneを諸種疾患々者17例に投与して， 血液凝固因子の変動を明らかにすると共に, 健 康老年者 20 例, 高血圧症18例，脳軟化症10例， 狭心症 13 例，心筋梗塞症 13 例，計74例を対象 己 して血漿17-OHCS Nelson \& Samuels 法に て測定し，同時に測定した血液凝固因子活性と 対比して, その関係を求め, 下記の成績を得, 更に血栓症の成因に就いて論及した.

1） prednisolone $25 \mathrm{mg}$ を10例に 1 回投与しそ の半数例に，又は 7 例に長期間投与し 6 例に prothrombin 時間の短縮, prothrombin 濃度の増 加，第 7 因子活性の上昇を認めた。第 5 因子活 性には，1回投与後は著变を認めなかつたが， 長期投与後には 6 例において増加がみられた。

2）血漿 17-OHCS は, 健康対照群に比し, 疾 患群では何れも有意の増加を示し, 特に脳軟化 症, 心筋梗塞症にその傾向が強く, 副腎皮質機 能六進を思わせる，又との 2 疾患では，発作後 1 及び 2 ケ月以内に測定した值は以後のものに 比して明らかに高值であつた。

3）血液凝固因子では，第 7 因子活性の有意の 増加汃此等疾患群に共通して認められ，第 5 因 子活性は，心筋梗塞群でのみ有意の増加を認め たが，prothrombin 濃度は対照群に比し有意差
が認められなかつた１段法 prothrombin時間 は, 高血圧症群, 狭心徰群を除いて, 何れも有 意の短縮を認めた，血栓症を伴つたものでは， 凝固因子の変動がより著明の傾向が認められ た.

4）血漿 17-OHCS 質と血液凝固因子活性との 関係は，血漿17-OHCS值の上畀に従つて prothrombin 時間は短縮する傾向が認められ，有意 の逆相関関係を示した. 前者と prothrombiu濃 度との間には一定の傾向を認めず，第 5 ，第 7 因子活性との間には有意の相関関係を認めた。

以上の結果より，血栓症の成立には副腎皮質 機能元進が関与し，てれが血液凝固性の元進を もたらすととが関係すると考光られる。

文献

1) Selye,H. : The story of the Adaptation syndrom : Acta, INC. Montreal, Canada 1952.

2) Selye,H. : Stress (The physiology and pathology of Exposure to stress) ACTA Med. Publ., Montreal 1950.

3 ) Selye, H. : Textbook of Endocrinology. ACTA Med. Publ., Ist Edition, Montreal, Canada. 1947.

4) Engel, E., Helmreich, M. L., Herlogh, J., Fabrae, J., Mullec, A.F., \& Mach, R. S. : Sem h p paris $31: 78.1955$.

5 ) Forsman, O. : Acta Med. Scand. Suppl. 296, 1954

6) Beaumont, J.L., Chevalier, H., \& Lenegre, J. : Am. Heart. J. 45 : 756, 1953.

7) Hartert, H. : Angina pectoris, Stuttgart 1954.

8) Heinecker, R., Lösch,H. W. : Medizinische 614. 1956

9 ) Szezelik, E. A., Tanikowa, A. : Zsch. inn. Med. 12 : 639. 1957.

10) Wessler, S. : J.Clin. Invesr. $34: 647.1955$.

11) Cosgriff, S. W. , Diefenbach, A, F., Vogt, W, 
(301)

Jr. : Am. J. Med. 9 : 752. 1950.

12) Stefanini, M., Martino. N. B. : N.E.J. Med. $254 \cdot 313.1956$.

13) Nelson, D. H., Samuels, L.T. : J. Clin. Endocrinol. Met. 12 : 519. 1952.

14) Quick, A. J. : Am. J. Med. Sci. $190: 501$. 1935.

15) Ware, A.G., Seegers, W. H. : J. Clin. pathol. $19: 471.1949$.

16) Lewis, M. L., Ware, A.G. : Proc. Soc. Exp. Biol \& Med. 84 : 640. 1953.

17) Koller, F., Loeliger, A. \& Duckert, F. : Acta Hematolg. 6 : 1. 1951.

18) Cosgriff, S.W. : J. A. M. A. 147. : 924. 1951.

19) Forattini, C., de Castro, B. \& Petrin,G. : Med. Klin. 1633. 1956.

20) Günther,P.Gg., Kiefer,E. : Med Klin. 1633. 1956.

21) de Nicola, P. : Schweiz. Med. Wschr. 84 : 835. 1954.

22) OKa, M. : Acat Med. Scandinav. $156: 221$. 1956.

23) Feldthusen, u., Lassen, N. A. : Acta Med. Scandinav. $150: 53.1954$.

24）長谷川透：日内会誌，48：540. 1959.

25）生方茂雄：脳已神経，11：847. 1959.

26）松沢義之：北関東医学， $9: 49.1959$.

27) 大塚 敬 : 北関東医学, $9: 22.1959$.

28）内分泌のつどい編集委員会 : ホルモン検査法 1956.
29) Proter, C. C., Silber, R. H. : J. Biol. Chem. $185: 201.1950$.

30) Smith, R. W., Mellinger, R.C. \& Patti, A. A. : J. clin Endoricnol \& Met $14:$ 336. 1954.

31) Burton, R. B. , Zaffaroni, A. \& Keutmann, E. H. : J. Biol. Chem. 188 : 763. 1951.

32) 村上元孝 内科, $1: 39.1958$.

33) Bush, I. E., Sandberg, A. A. : J. Biol. Chem. 205 : 783. 1953.

34) Bayliss, R. I. S. : Brit. M. J. 1 : 495. 1955.

35) Forsman, O. : Acat Med. Scandinav. 156 : 221. 1956.

36) Friedman, M., Uhley, H. N. : Am. J. physiol. 197 : 205. 1959.

37) Smith, R.W., Margulis, R.R., Brennan, M. J., Manto, R. W. : Sceience 112 : 295. 1950.

38) Eleanor, Z.W., Nicholas, P.C., Joseph, W.J. : J. Clin. Endocri \& Metab. 15. : 1073. 1955.

39) Staehelin, D., Labhart, A., Froesch, R. \& Kögi, H.R : Acta Endocrinol 18 : 521. 1955

40) William, J.E., Robert, J.S. \& Alfred. M. B : Am. J. Med. 13 : 27.1952.

41) Poller, L. : J. Clin. Pathol. 10 : 347. 1957.

42) Hellem, A. J., Solem, J. H. : Acta Med. Scand. $150: 389.1954$.

43）村上元孝 : 日本臨床, 16 : 154. 1958.

44) Adlersberg, D., Stricker, J., Himes, H. : J. A. M. A. 159 : 1731.1955.

45) 沖中, 西川：最新医学, $11: 86.1956$. 


\title{
STUDIES ON THE CHANGES IN ADRENOCORTICAL FUNCTION AND BLOOD CLOTTING FACTOR AND THEIR SIGNIFICANCE IN THE DEVELOPMENT OF ARTERIAL THROMBOSIS
}

\author{
Kaoru Hanawa \\ 2 nd Department of Internal Mediciue School of Medicine, Gunma University \\ (Director : Prof. K. Nakao and Prof. M. Murakami)
}

In order to elucidate the mechanism concerning the development of arterial thrombosis, various blood coagulation factors and plasma 17-OHCS levels were determined in 18 cases of hypertension, 10 cases ob cerebromalacia, 13 cases of angina pectoris, 13 cases of myocardial infarction and 20 normal subjects simultaneously. Furthermore, effects of single or daily administration of prednisolone on the blood coagulation were observed in 17 cases with various diseases. The results obtained were as follows:

1. Shortening of prothrobinm time, increase in prothrombin concentration or factor 7 activity were observed in half of 10 patients in $6 \sim 9$ hours after single oral dose of $25 \mathrm{mg}$ of prednisolone. The daily administration of prednisolone was followed by similar changes in 6 out of 7 cases.

In this case, an increase in factor 5 activity was obtained in 6 cases, although no remarakable change was found after single dose.

2. Plasma 17-OHCS levels were significantly increased in patients with hypertension, angina pectoris, cerebromalacia or myocardial infarction. The levels tended to be higher in the latter two diseases, especially in fresh cases.

3. Significant increase in factor 7 activity was observed in all these patients, while significant increase in factor 5 activity was seen only in patients with myocardial infarction. In patients with cerebromalacia or myocardial infarction, one stage prothrombin time was significantly shortened. No significant increase in prothrombin concentration was found in all these patients. Changes in these blood clotting factors were more remarkable in patients with arterial thrombosis. From the clinical observation, these changes seemed to be related to the development of arterial thrombosis.

4. There was highly significant inverse relationship between 17-OHCS levels in plasma and one stags prothrombin time. Similarly, significant relationship was observed between 17-OHCS levels and factor 5 or 7 activity. There was no correlation between 17-OHCS levels and prothrombin concentration.

From the results above described, it is concluded that adrenocotrical hyperfunction may be responsible for an increase in blood coagulability and the development of thrombosis. 